\title{
Monolayer Structures of Highly Photoluminescent Furan Oligoaryls: An Approach to Improve Packing Crystallinity of Dithiolated Aromatics
}

\author{
Shu-Yi Lin,${ }^{\dagger}$ I-Wen Peter Chen, ${ }^{\dagger}$ Chun-hsien Chen, ${ }^{*}, \dagger$ Chin-Fa Lee, ${ }^{\ddagger}$ Chih-Ming Chou, ${ }^{\ddagger}$ and \\ Tien-Yau Luh*, \\ Department of Chemistry, National Tsing Hua University, Hsinchu, Taiwan 30013, Department of Chemistry, \\ National Taiwan University, Taipei, Taiwan 106
}

Received: December 9, 2004; In Final Form: February 24, 2005

\begin{abstract}
We demonstrated that mono- and dithiolated furan-containing oligoaryls (II-IV, see Chart 2) can be successfully synthesized via a one-pot strategy starting from propargylic dithioacetals. IRAS (infrared reflection-absorption spectroscopy) and STM (scanning tunneling microscopy) experiments revealed that single-component monolayers of II, III, and IV are essentially disordered, an important property that prevents excited photoluminescent molecules from self-quenching in the organic layers of an OLED device. Surprisingly, localized lattice packing of crystalline dithiolated furan oligoaryls on $\mathrm{Au}(111)$ can be assembled by immersing preadsorbed $n$-dodecanethiol SAMs in the corresponding deposition solutions. The discrepancy in the formation of disordered or localized crystalline structures is discussed. For single-component monolayers, the facile formation of $\mathrm{S}-\mathrm{Au}$ bonds generates chaotically distributed monolayers in which the arched molecules hinge each other and block the desorptive pathways. The absence of crystalline packing is mainly attributed to the difficulty for the dithiols to simultaneously break two $S-A u$ bonds, to desorb, and then to readsorb, the key step to improve the intermolecular attractions for crystalline SAMs. By preassembling $n$-dodecanethiol SAMs, the space for dithiolated compounds III and IV to adsorb is limited to domain boundaries or packing defects where crystalline packing of III and IV can grow.
\end{abstract}

\section{Introduction}

Conjugated oligomers with tailored constituents and precisely controllable length have been a current research interest because of their potential applications in molecular wires and optoelectronics. ${ }^{1,2}$ The electric and optoelectronic properties of conjugated oligoaryls can occasionally be fine-tuned by integrating with heteroaromatic rings (e.g., oligothiophenes, ${ }^{2-8}$ tetrathiafulvalene, ${ }^{9-12}$ or pyrroles $\left.{ }^{1-4,13,14}\right)$. Furan-containing oligoaryls, ${ }^{7,8,15-18}$ representing a new class of materials, are relatively unexplored. We recently developed a new annulation procedure for the synthesis of 2,3,5-trisubstituted furans from the corresponding propargylic dithioacetals. ${ }^{19-22}$ This protocol can conveniently introduce at $\mathrm{C}_{3}$ position in the furan ring an alkyl substituent, which increases the solubility in organic solvents and thus improve the processibility of these materials. ${ }^{19-22}$ It has recently been shown that I (Chart 1) exhibited excellent hole-transport properties with low turn-on voltage, high efficiency, high brightness, and high hole mobility, comparable with those of conventional arylamine-based hole-transport materials..$^{23,24}$ The Bassler formalism, ${ }^{25-30}$ referred as a disorder model, was utilized to fit the measured mobility, and the results of data analysis indicated that the layer containing I prepared in the OLED device was essentially disordered, presumably resulting from the steric influence and nonplanar structure. ${ }^{19,23}$ Such steric hindrance and thus disorderness are favorable in conserving excited fluorophores from self-quenching because of film crystallization.

* Authors to whom correspondence should be addressed. E-mail: chhchen@mx.nthu.edu.tw (C.-h.C.), tyluh@ntu.edu.tw (T.-Y.L.). Phone: +8863 5737009 (C.-h.C.), +886223636288 (T.-Y.L.). Fax: +8863 5711082 (C.-h.C.), +8862 23644971 (T.-Y.L.)

National Tsing Hua University.

$\doteqdot$ National Taiwan University.
CHART 1: Structure of Furan, 2,2'-[1,1'-biphenyl]-4,4'diylbis[3,5-diphenyl-

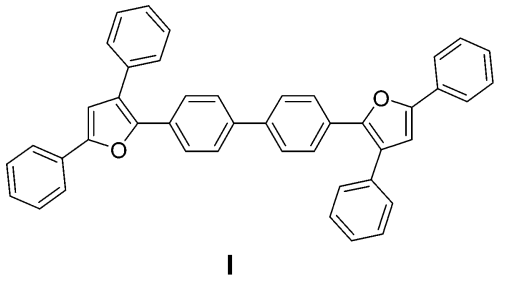

Over the past decade, the concept of engineering thioaromatic self-assembled monolayers (SAMs) $)^{31-46}$ as the building blocks for molecular electronics ${ }^{45,47-55}$ has stimulated enormous research activities. There are two general findings for structural characterization of $\mathrm{X}-\left(\mathrm{C}_{6} \mathrm{H}_{4}\right)_{m}-\mathrm{SH}$ SAMs on gold. First, the sulfur headgroup preferentially adopts the $\mathrm{sp}^{3}$ binding scheme on gold substrate. ${ }^{35,56-58}$ For thiolphenol $(\mathrm{Ph}-\mathrm{SH})$ and biphenylthiol, the tilt angle of the phenyl introduces steric hindrance between neighboring molecules and, therefore, their SAMs are ill-defined. ${ }^{34-37,58-64}$ By inserting a methylene unit between the phenyl ring and the thiol group (i.e., $\mathrm{Ph}-\mathrm{CH}_{2}-\mathrm{SH}$ ), the steric constraint is released and the SAMs become well-ordered. ${ }^{35,56-58,65}$ Second, for those not containing a benzyl moiety, increasing intermolecular $\pi-\pi$ interactions by increasing the number of phenyl rings improves the film crystallinity. ${ }^{34-38,66}$ In this IRAS (infrared reflection-absorption spectroscopy) and STM (scanning tunneling microscopy) study, we examined the SAM structures of planar furan-containing oligoaryls (II-IV shown in Chart 2), analogues of I that appear disordered as a holetransport layer in an OLED device (vide supra). Given that the conjugated and planar aryls favorable to the strong neighboring $\pi-\pi$ stacking, the benzyl group adaptable with the $\mathrm{sp}^{3}$ 

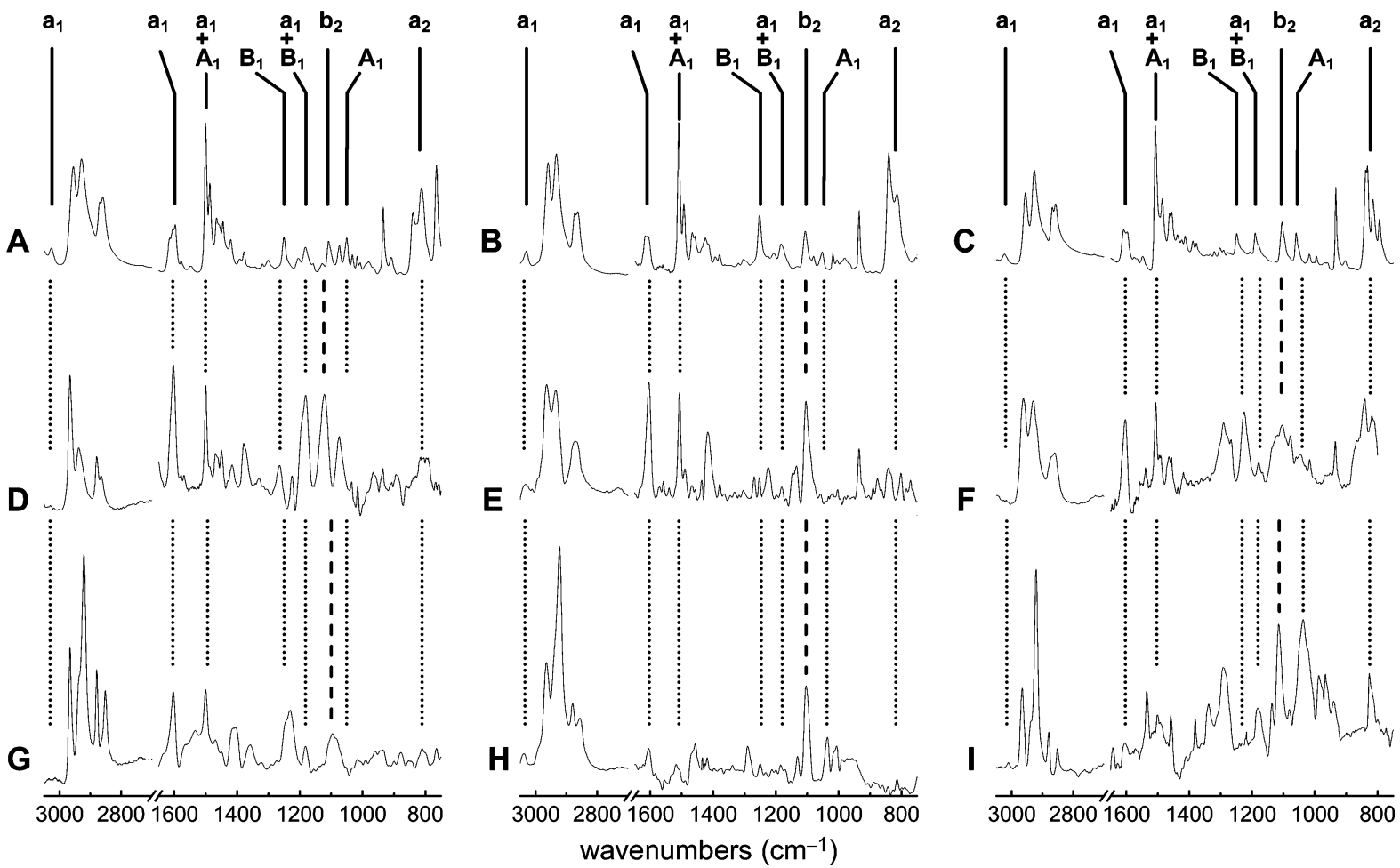

Figure 1. Transmission and IRAS spectra of compounds II-IV. Samples prepared in KBr pellets: (A) II, (B) III, and (C) IV. Transmittance is converted into absorbance for better comparison with IRAS spectra. Spectra of single-component films: (D) II, (E) III, and (F) IV. Mixed monolayer spectra of (G) II, (H) III, and (I) IV-containing films prepared in $n$-dodecanethiol preassembled gold substrate. The assignments of vibrational modes are tabulated in Table 1 .

\section{CHART 2: Structures of Thiolated Furan-containing Oligoaryls}

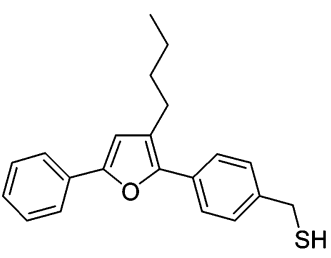

II

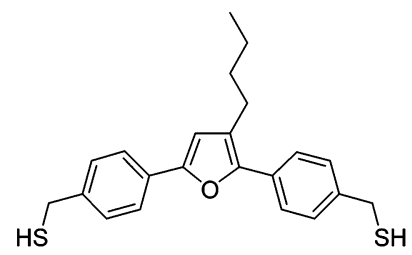

III

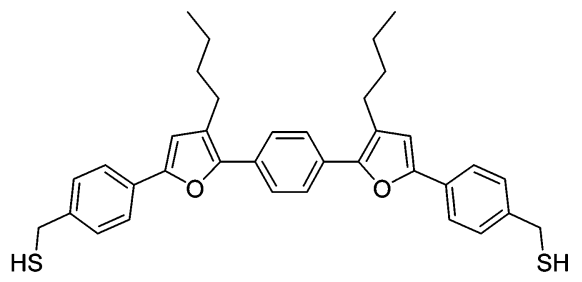

IV hybridization of $\mathrm{S}-\mathrm{Au}$ bond, and $n$-butyl side chains that introduce steric effects, it is interesting to find out which factor dominates and whether such furan-containing oligoaryl monolayers are crystalline or disordered, a crucial factor for the organic layer of OLED devices. Also explored is improvement in the packing structure of such branched mercaptoaryls, an important subject in monolayer assembly.

\section{Results}

IRAS measurements. Typical IR spectra of II, III, and IV prepared in $\mathrm{KBr}$ pellets are shown in panels $\mathrm{A}, \mathrm{B}$, and $\mathrm{C}$ of Figure 1, respectively. The molecules in $\mathrm{KBr}$ pellets are grinded thoroughly and thus are presumably oriented isotropically. The characteristic vibrational peaks for furan $\left(\mathbf{A}_{\mathbf{1}} \text { and } \mathbf{B}_{1}\right)^{67,68}$ and the disubstituted para-benzene moiety $\left(\mathbf{a}_{1}, \mathbf{a}_{2} \text {, and } \mathbf{b}_{2}\right)^{69-71}$ are denoted. The bands at $2965-2850 \mathrm{~cm}^{-1}$ are the stretch modes for $n$-butyl $\left(v_{\mathrm{CH} 2}\right.$ and $\left.v_{\mathrm{CH} 3}\right){ }^{72-76}$ Summarized in Table 1 are the peak positions and the vibrational modes assigned according to literature reports of similar moieties. ${ }^{67-76}$ The band at $\sim 1504$ $\mathrm{cm}^{-1}$ is the result of overlap of an $\mathbf{A}_{\mathbf{1}}$ mode of furan moiety ${ }^{67}$ with an $\mathbf{a}_{1}$ of phenyl. ${ }^{69}$ Because the two vibrational modes are somewhat perpendicular to each other, these bands are not used to discuss the molecular orientation.

Panels D, E, and F in Figure 1 are, respectively, IRAS spectra of the single-component monolayers on gold for II, III, and
IV. The $v(\mathrm{SH})$ mode is indiscernible, suggesting the formation of a $\mathrm{S}-\mathrm{Au}$ bond. For the convenience of the following discussion, the transition dipoles ${ }^{69,77}$ of the para-benzene moiety relative to the surface normal are sketched in Figure 2 in which $\mathbf{a}_{1}$ (ca. 3052 and $\left.1604 \mathrm{~cm}^{-1}\right)$ and $\mathbf{b}_{2}\left(\sim 1106 \mathrm{~cm}^{-1}\right)$ are in-plane vibrational modes and are, respectively, parallel and perpendicular to the $C_{2 v}$ axis of this group; $\mathbf{a}_{2}\left(\sim 833 \mathrm{~cm}^{-1}\right)$ is an outof-plane mode. For the furan moiety, the in-plane bending modes $\mathbf{A}_{1}$ and $\mathbf{B}_{1}$ are parallel and perpendicular to the $C_{2 v}$ axis, respectively. The relative peak intensities of Figure 1D-F are quite different than those of the corresponding spectra measured in $\mathrm{KBr}$ pellets (Figure $1 \mathrm{~A}-\mathrm{C}$ ). The intensity ratios of $I_{\mathbf{b} 2} /$

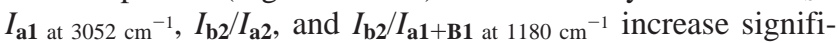
cantly. Because the peak intensities obtained from $\mathrm{KBr}$ pellets represent transition dipoles oriented isotropically and because IRAS for metallic substrates is insensitive to transition dipole perpendicular to the surface normal, ${ }^{78,79}$ the increase in these intensity ratios suggests a plausible structure proposed in Figure $2 \mathrm{~A}$ in which the long axes of the benzene rings (i.e., $\mathbf{a}_{1}$ ) are somewhat perpendicular to the surface normal. For the other $\mathbf{a}_{1}$ at $1603 \mathrm{~cm}^{-1}$, however, the magnitude of $I_{\mathbf{b} 2} / I_{\mathbf{a} 1}$ ratios of the single component film compared to the corresponding compound in $\mathrm{KBr}$ is slightly larger for II, about the same for III, and only one-half of those in $\mathrm{KBr}$ for IV (Table 2). These ratios suggest ill-defined SAMs with probable multiple orientations. The peak 
TABLE 1: Peak Assignments for Furan-containing Oligoaryls in KBr Pellets and in Monolayers Mixed with Dodecanethiol

\begin{tabular}{|c|c|c|c|}
\hline \multicolumn{2}{|c|}{ peak position $\left(\mathrm{cm}^{-1}\right)$} & \multirow[b]{2}{*}{ vibrational mode ${ }^{b}$} & \multirow[b]{2}{*}{$\begin{array}{l}\text { transition dipole } \\
\text { direction }^{c}\end{array}$} \\
\hline in $\mathrm{KBr}$ & $\begin{array}{l}\text { in mixed } \\
\text { monolayers }\end{array}$ & & \\
\hline 3052 & $--^{a}$ & $v_{2 \mathrm{a}}(\mathrm{CH})$, in-plane stretching & phenyl ring: ${ }^{d} \mathbf{a}_{1}$ \\
\hline 2965 & 2963 & $v_{\mathrm{a}}\left(\mathrm{CH}_{3}, \mathrm{ip}\right)$, asym stretching & \\
\hline 2933 & 2937 & $v_{\mathrm{s}}\left(\mathrm{CH}_{3}, \mathrm{FR}\right)$, sym stretching & \\
\hline$--^{a}$ & 2920 & $v_{\mathrm{a}}\left(\mathrm{CH}_{2}\right)$, asym stretching & \\
\hline 2868 & 2871 & $v_{\mathrm{s}}\left(\mathrm{CH}_{3}\right)$, sym stretching & \\
\hline 2859 & 2860 & $v_{\mathrm{s}}\left(\mathrm{CH}_{2}\right)$, sym stretching & \\
\hline 2567 & $--^{a}$ & $v(\mathrm{SH})$ & \\
\hline 1607 & 1603 & $v_{8 \mathrm{a}}(\mathrm{C}=\mathrm{C})$, in-plane stretching & phenyl ring: ${ }^{d} \mathbf{a}_{1}$ \\
\hline 1508 & $1504-1491$ & $\begin{array}{l}v_{19 \mathrm{a}}(\mathrm{C}=\mathrm{C}), \text { in-plane stretching } \\
v(\mathrm{C}=\mathrm{C}), \text { in-plane ring stretching }\end{array}$ & $\begin{array}{l}\text { phenyl ring: }:^{d} \mathbf{a}_{1} \\
\text { furan: }^{e} \mathbf{A}_{1}, \| C_{2 v} \text { axis }\end{array}$ \\
\hline 1465 & 1465 & $\left.\delta\left(\mathrm{CH}_{2}\right)\right)$, deformation & \\
\hline 1250 & 1265 & $\delta(\mathrm{CH})$, in-plane bending & furan: ${ }^{e} \mathbf{B}_{\mathbf{1}}, \perp C_{2 v}$ axis \\
\hline 1180 & 1180 & $\begin{array}{l}v_{19 \mathrm{a}}(\mathrm{C}=\mathrm{C}) \text {, in-plane stretching } \\
\delta(\mathrm{CH}) \text {, in-plane bending }\end{array}$ & $\begin{array}{l}\text { phenyl ring: }{ }^{d} \mathbf{a}_{\mathbf{1}} \\
\text { furan: }{ }^{e} \mathbf{B}_{\mathbf{1}}, \perp C_{2 v} \text { axis }\end{array}$ \\
\hline 1107 & 1106 & $v_{18 \mathrm{~b}}(\mathrm{CH})$, in-plane bending & phenyl ring: ${ }^{d} \mathbf{b}_{2}$ \\
\hline 1060 & 1041 & $\delta(\mathrm{CH})$, in-plane bending & furan: ${ }^{e} \mathbf{A}_{\mathbf{1}}, \| C_{2 v}$ axis \\
\hline 833 & 820 & $v_{10 \mathrm{a}}(\mathrm{CH})$, out-of-plane bending & phenyl ring: ${ }^{d} \mathbf{a}_{2}$ \\
\hline
\end{tabular}

${ }^{a}$ The peak intensity is negligible. ${ }^{b}$ Subscripts: a, asymmetric; s, symmetric; numbers, modes defined in ref $69 .{ }^{c}$ The directions of the transition dipoles with respect to the molecule plane are depicted in Figure 2. ${ }^{d}$ Ref $69 .{ }^{e} \operatorname{Ref} 67$.

A
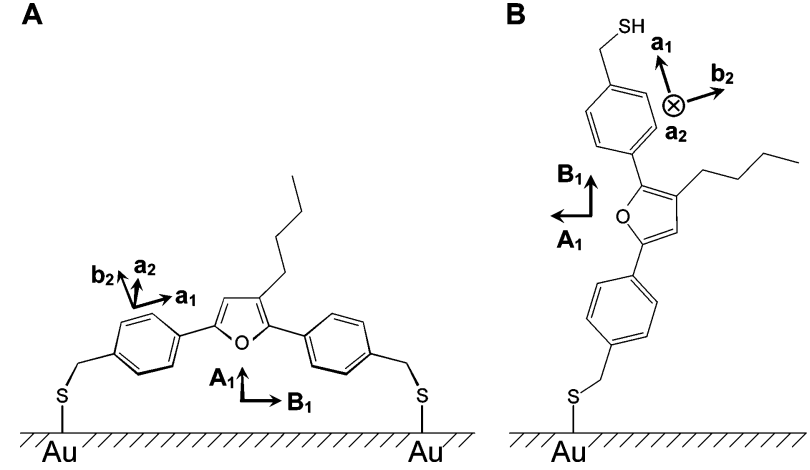

Figure 2. Proposed binding schemes for III self-assembly and corresponding vibrational modes for para-benzene and furan moieties.

intensity of $\mathbf{a}_{2}$ mode (out-of-plane) at $820 \mathrm{~cm}^{-1}$ is distinct, indicative of a large tilting angle of the phenyl rings away from the surface normal. Most likely, although the furan-containing oligoaryls on gold adopt a preferential orientation resembling Figure 2A, the packing is disordered in nature, consistent with the mobility measurements for $\mathbf{I}$ (vide supra). ${ }^{24}$

Panels G, H, and I of Figure 1 are typical IRAS spectra of mixed monolayers prepared by immersing substrates of preassembled $n$-dodecanethiol SAMs into the oligoaryl deposition solutions. For mixed monolayers of II/dodecanethiol SAMs, the out-of-plane band $\mathbf{a}_{2}$ becomes indistinct and the intensity ratios of $I_{\mathbf{b} 2} / I_{\mathrm{a} 1}$ at $1603 \mathrm{~cm}^{-1}($ Table 2$)$ and $I_{\mathbf{A} 1} / I_{\mathbf{B} 1}$ are smaller than those in $\mathrm{KBr}$, suggesting an orientation similar to that of Figure 2B for II (monothiol). However, no lattice structure was found by STM (vide infra). For III and IV, the ratios of $I_{\mathbf{b} 2} / I_{\mathbf{a} 1}, I_{\mathbf{A} 1} / I_{\mathbf{B} 1}$,

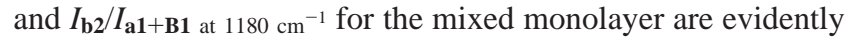
larger than those in $\mathrm{KBr}$ pellets and in single-component monolayers. The attenuation in peak ratios supports the formation of the structure shown in Figure 2A and rules out the possibility of Figure 2B, which would require that the ratios of $I_{\mathrm{b} 2} / I_{\mathrm{a} 1}$ and $I_{\mathrm{b} 2} / I_{\mathrm{a} 2}$ be smaller than those in $\mathrm{KBr}$ pellets. The outof-plane mode $\left(\mathbf{a}_{2}\right.$ at $\left.820 \mathrm{~cm}^{-1}\right)$ becomes very small in Figure $1 \mathrm{H}$ and still significant in Figure 1I, suggesting that the molecular tilt angle of the phenyl rings for III is smaller that that of IV. Taken together, the spectra indicate a better uniformity of the molecular orientation in mixed monolayers than that in single-component films.
STM Measurements. Numerous attempts in adjusting deposition time, concentrations of II-IV, and solvent selection have been carefully carried out. However, STM provides no indication that the single-component SAMs are well-ordered nor exhibit well-defined stacking of oligoaryls even within small domains, suggesting ill crystallinity for the branched furan oligoaryls on gold substrate. Mixed monolayers of monothiol II/dodecanethiol do not show lattice packing of II by STM. Surprisingly, images of well-ordered structures for striped III and IV domains can be found in mixed monolayers (Figure 3). Although missing row and low-density SAMs of $n$-alkanethiol exhibit pinstriped phases, this is unlikely the case on the basis of the assessment stated in the following. First, the unit-cell symmetry for these missing row and low-density $n$-alkanethiol SAMs is close to rectangular, ${ }^{80-84}$ different than those of III and IV whose angles between the unit cell vectors are $60^{\circ}$ and $76^{\circ}$, respectively. Literature of low-density $n$-dodecanethiol SAMs is rare. Godin et al. recently reported a stacked lying-down structure for lowdensity $n$-dodecanethiol SAMs. ${ }^{85}$ The length of the observed stripe is $1.5 \mathrm{~nm},{ }^{85}$ significantly smaller than our findings for crystalline domains of III and IV (vide infra). Second, spectra of STS (scanning tunneling spectroscopy) for the striped III and IV domains are distinct from those for the $n$-dodecanethiol matrix. The STS spectra are provided in the supporting material because the results are not pertinent to this present study and the detailed investigations of STS for the branched furan oligoaryls are still ongoing. Third, we did parallel experiments that, under the same conditions as those for preparing striped III and IV domains, the preassembled $n$-dodecanethiol SAMs were re-immersed in either monothiol II or THF blank solution. Striped features such as those of crystalline III and IV domains were not found.

Panels A, B, and C of Figure 3 are STM images of III/dodecanethiol mixed monolayers; panel D is obtained from SAMs containing IV. The upper part of Figure 3A and the lower part of Figure 3B show large domains of $\mathrm{c}(4 \times 2)$, characteristic of $n$-alkanethiol SAMs on $\mathrm{Au}(111) .{ }^{86,87}$ Around domain boundaries at the lower left corner of panel A and the upper part of panel B, the images reveal packing of III. The stacking pattern is different from that of the $c(4 \times 2)$ and exhibits a 3 -fold symmetry (inset of panel A). The inset of panel B is an enlarged view of the $c(4 \times 2)$ structure of dodecanethiol. Because of the 
TABLE 2: Relative Intensities of Representative Vibrational Modes of II-IV in KBr Pallets and in Monolayers

\begin{tabular}{|c|c|c|c|c|c|c|c|c|c|}
\hline \multirow[b]{4}{*}{ vibrational mode } & \multicolumn{9}{|c|}{ peak intensity $\left(\times 10^{4}\right.$ arbitrary unit $)$ and intensity ratio } \\
\hline & \multicolumn{3}{|c|}{ compound II } & \multicolumn{3}{|c|}{ compound III } & \multicolumn{3}{|c|}{ compound IV } \\
\hline & \multirow[b]{2}{*}{ in $\mathrm{KBr}$} & \multicolumn{2}{|c|}{ monolayers } & \multirow[b]{2}{*}{ in $\mathrm{KBr}$} & \multicolumn{2}{|c|}{ monolayers } & \multirow[b]{2}{*}{ in $\mathrm{KBr}$} & \multicolumn{2}{|c|}{ monolayers } \\
\hline & & II only ${ }^{a}$ & $\operatorname{mixed}^{b}$ & & III only ${ }^{a}$ & $\operatorname{mixed}^{b}$ & & IV only ${ }^{a}$ & $\operatorname{mixed}^{b}$ \\
\hline $\mathbf{b}_{2}\left(1106 \mathrm{~cm}^{-1}\right)$ & 1489.2 & 3.3 & 3.1 & 208.4 & 6.1 & 6.8 & 743.3 & 6.8 & 7.9 \\
\hline $\mathbf{a}_{1}\left(1603 \mathrm{~cm}^{-1}\right)$ & 1945.1 & 3.1 & 6.2 & 188.0 & 6.7 & 2.4 & 662.5 & 13.1 & 1.5 \\
\hline$I_{\mathrm{b} 2} / I_{\mathrm{a} 1}$ & 0.77 & 1.1 & 0.50 & 1.1 & 0.91 & 2.8 & 1.1 & 0.52 & 5.3 \\
\hline
\end{tabular}

${ }^{a}$ Single-component monolayers. ${ }^{b}$ Assembled on dodecanethiol-preadsorbed monolayers.
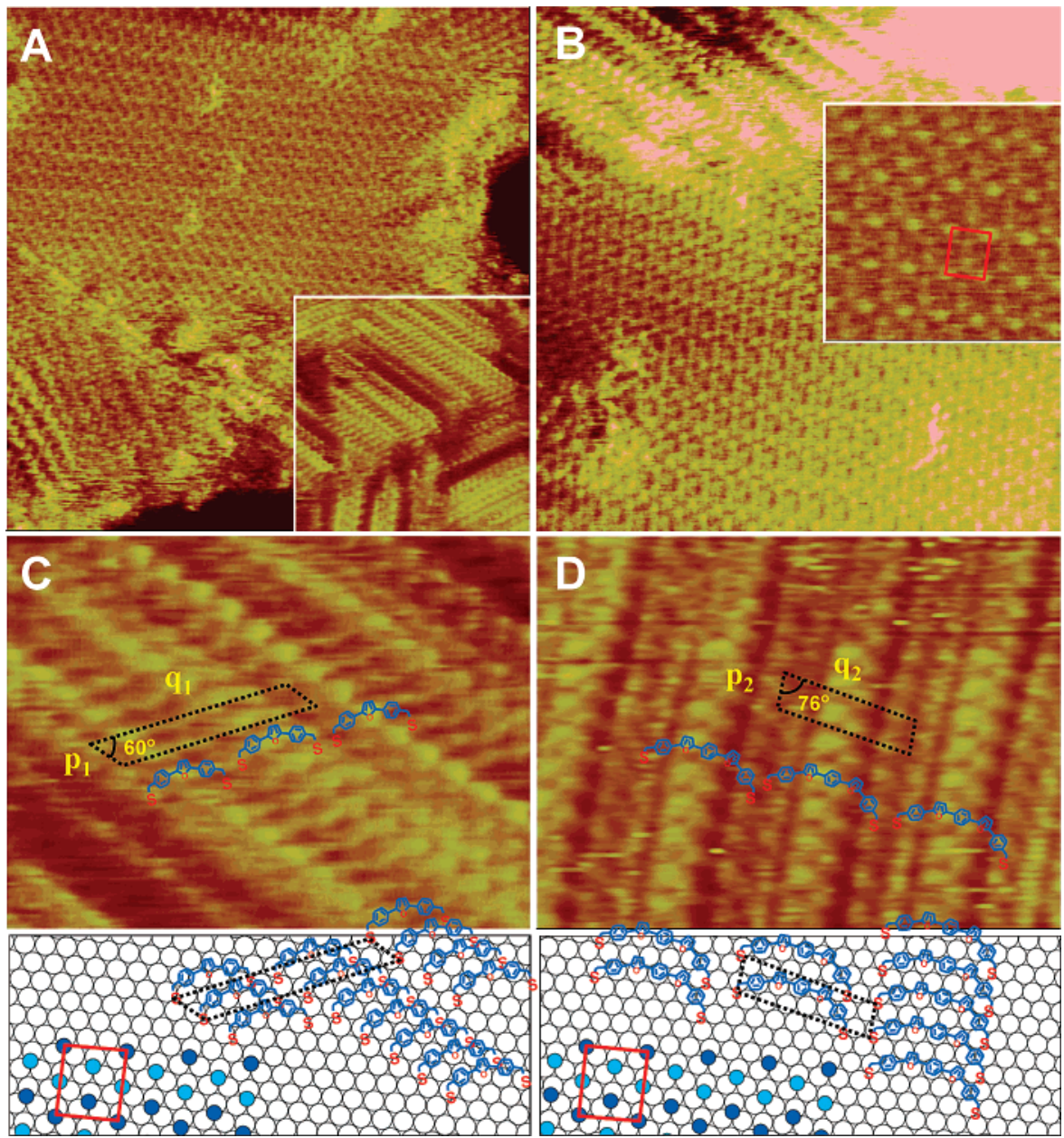

Figure 3. STM images of mixed monolayers of (A-C) III and $n$-dodecanethiol, (D) IV and $n$-dodecanethiol on Au(111). Imaging size: (A) 30 $\mathrm{nm} \times 30 \mathrm{~nm}$, (B) $20 \mathrm{~nm} \times 20 \mathrm{~nm}$, (C) $8.5 \mathrm{~nm} \times 6.5 \mathrm{~nm}$, and (D) $8.5 \mathrm{~nm} \times 6.5 \mathrm{~nm}$; typical imaging conditions: $V_{\text {bias }}, 1.4 \mathrm{~V} ; i_{\mathrm{t}}, 12 \mathrm{pA}$. The inset in (A) shows the image of three domains of III, imaging size: $17 \mathrm{~nm} \times 17 \mathrm{~nm}$. The inset in (B) magnifies the characteristic c $(4 \times 2)$ unit cell of $n$-dodecanethiol SAMs. The bottom parts of (C) and (D) illustrate proposed packing structures of dodecanethiol, III, and IV. The $n$-butyl group is omitted for clarity. Note that, for III (C), one thiol is designated to lodge at a 3-fold hollow site while the other at a bridging site. Other arrangements with the sulfur atoms in the 3 -fold hollow, bridging, or ontop sites are also possible.

well-established correlation of the $\mathrm{c}(4 \times 2)$ unit cell with respect to that of the underlayer $\mathrm{Au}(111)$, the angles of unit cell vectors of $c(4 \times 2)$ relative to those of III and IV lead us to deduce their lattice structures on $\mathrm{Au}(111)$. Higher magnified images for III and IV stacking are presented in panels C and D of Figure 3. Position of the butyl cannot be identified because of its fluxional nature at room temperature. The nominal width of the stripes in panels C and D (i.e., $\left|\mathbf{q}_{\mathbf{1}}\right|$ and $\left|\mathbf{q}_{\mathbf{2}}\right|$ in Figure 3) are 2.50 and $2.02 \mathrm{~nm}$, which correlate well with the length of the corresponding molecules and are, respectively, equivalent to $5 \sqrt{3}$ and $4 \sqrt{3}$ times gold diameter. Along the direction of $\mathbf{p}$, the molecules do not exhibit modulation in height, and the respective spacings for III and IV are $0.51 \pm 0.03 \mathrm{~nm}$, consistent with $\sqrt{ } 3$ times the Au spacing. In consequence, vector $\mathbf{p}$ is commensurate with the $\langle 121\rangle$ direction of $\mathrm{Au}(111)$. The models shown in panels $C$ and $D$ are a $(\sqrt{ } 3 \times 5 \sqrt{ } 3)$ structure for III and a $(\sqrt{ } 3 \times 4 \sqrt{ } 3)$ for IV where the angles between the unit cell vectors ( $\mathbf{p}$ and $\mathbf{q}$ ) are ca. $60^{\circ}$ and $76^{\circ}$, respectively. At the bottom parts of the images are the proposed models of molecular stacking and unit cells that illustrate the reason the images appear curvy and alternating with bright and dark rolls. This feature is ascribed to the arch-shaped conformation of the furan-containing oligoaryls where the central part is higher than the arms (Chart 2 and Figure 2A).

\section{Discussion}

In the study of single-component monolayers of furancontaining oligoaryls, results of FTIR and STM imaging unveil 


\section{SCHEME 1}

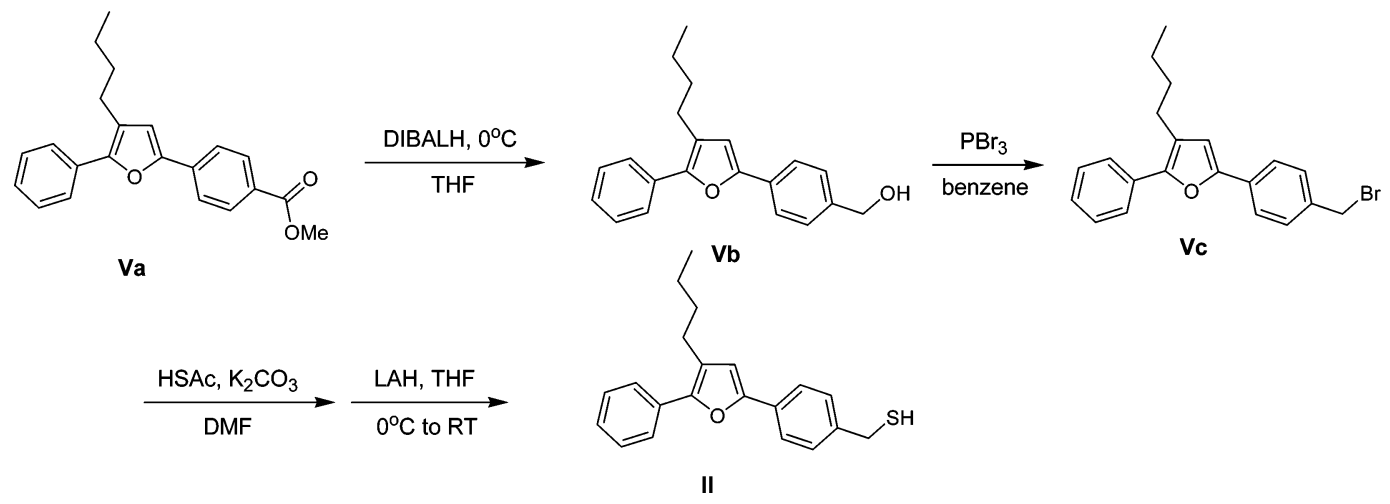

disordered molecular monolayers, demonstrating that the steric effect arising from the butyl group and the arched molecular shape are the dominant factors on monolayer structures even though the intermolecular attractions are contributed from as many as 5 aromatic rings. The finding reconfirms our previous analysis that the thin films of these oligoaryls are not crystalline and are suitable for OLED devices. ${ }^{23,24}$

We manage to obtain crystalline domains of III and IV by exposing preassembled $n$-dodecanethiol SAMs in the corresponding deposition solutions. Several novel and intriguing findings are discovered: (1) the stacking features of II-IV cannot be found without the presence of dodecanethiol SAMs, (2) the long axes of the molecules and their aryl planes are, respectively, perpendicular to and slightly tilted away from the surface normal, an unprecedented packing structure in exclusively upright $\omega$-dithiol aromatic SAMs, ${ }^{31,32,55}$ and (3) the domains are small and appeared to reside against the welldefined $\mathrm{c}(4 \times 2)$ of $n$-dodecanethiol SAMs.

The assembly of the stacking features should take place during the exchange of dodecanethiol by III and IV because of the absence of in-film crystallinity for single-component SAMs. This assembling process is in essence the same as mixedmonolayer preparation, where surface-bound thiols are displaced by excess free thiols in solution. In literature reports, such exchange reactions are generally associated with a fast and a slow step although the experimental conditions are very different in molar ratios of free to surface-bound molecules and in properties of solvents and molecules. ${ }^{88-90}$ The fast step takes place at defects, such as domain boundaries of the alkanethiol SAMs, where free thiols can reach the gold surface relatively easily. At terraces or domains where the molecules are tightly packed, the kinetics is so slow that the exchange remains incomplete for reactions taking longer than 10 days. ${ }^{88-90}$ Accordingly, the packing stripes of III and IV are situated against the $\mathrm{c}(4 \times 2)$ domain of dodecanethiol SAMs.

Why and how do the preassembled dodecanethiol SAMs assist the stacking of III and IV? The arched shape of III and IV allows them to bind on gold substrate with two thiol legs. In the case of single-component SAMs, the oligoaryls chemisorb readily on bare gold because of the ease in developing the $\mathrm{S}-\mathrm{Au}$ bond. The promptness of chemisorption generates chaotically distributed monolayers in which the arched molecules hinge each other and block the desorptive pathways. It is difficult for the dithiols to simultaneously break two $\mathrm{S}-\mathrm{Au}$ bonds, to desorb, and then to readsorb, the key step of refining the intermolecular attractions for crystalline monolayers. ${ }^{36,41}$ Consequently, the steric effect of the branched furan oligoaryls governs the developed structures. In the case of mixed monolayers, the adsorption rate of III and IV is regulated by the slow desorption of dodecanethiols at domain boundaries. The adsorption sites are confined in a limited area where the furan-containing oligoaryls are unlikely to be jam-packed and, nonetheless, provides a sufficient space to maneuver the thiol legs to a thermodynamically favorable location. In the process of repetitively exchanging dodecanethiol and the dithiols (III and IV) within a confined space, the $\pi-\pi$ attractions of the aromatics become dominant and generate the stripe stacking whose butyl groups no longer impose steric hindrance.

In summary, we have shown that the one-pot strategy starting from propargylic dithioacetals can successfully synthesize thiolated furan-containing oligoaryls (II-IV). General procedures of preparing SAMs by soaking substrates in the deposition solutions result in ill-defined SAMs. The lack of lattice structure is attributed to the steric side chain, the rigid and arched molecular geometry, and the dithiol legs, which require simultaneous desorption of the thiolates and make it difficult to improve the intermolecular attractions. By preassembling $n$ dodecanethiol SAMs, the space for the furan-containing oligoaryls to reside is limited to domain boundaries where crystalline packing of III and IV can grow.

\section{Experimental Section}

Chemical Materials. All chemicals were used as received unless otherwise noted. The synthetic procedures for compounds II-IV are described in the following where the starting materials were prepared on the basis of those reported previously. ${ }^{19-24}$

Synthesis of Teraryl-mono-thiol (II). Teraryl-mono-ol ( $\mathrm{Vb})$. Under argon atmosphere, a THF solution $(60 \mathrm{~mL})$ of $\mathbf{V a}(1.25$ g, $3.7 \mathrm{mmol})$ was treated with DIBALH $(16.0 \mathrm{~mL}$ of $1.0 \mathrm{M}$ solution, $16.0 \mathrm{mmol}$ ) at $0{ }^{\circ} \mathrm{C}$. The mixture was stirred for 30 min at $0{ }^{\circ} \mathrm{C}$ and was gradually warmed to room temperature and stirred for $5 \mathrm{~h}$. After quenching with $10 \% \mathrm{NH}_{4} \mathrm{Cl}(10 \mathrm{~mL})$ and extracted with ether, the organic layer was dried with $\mathrm{MgSO}_{4}$, and then the solvent was removed in vacuo. The residue material was recrystallized from $\mathrm{CH}_{2} \mathrm{Cl}_{2}$-hexane to give the $\mathbf{V b}$ (903 mg, 79\%) mp 65-66 ${ }^{\circ} \mathrm{C}:{ }^{1} \mathrm{H}$ NMR $\left(300 \mathrm{MHz}, \mathrm{CDCl}_{3}\right) \delta$ 0.95 (t, $J=7.4 \mathrm{~Hz}, 3 \mathrm{H}$ ), 1.43 (sextet, $J=7.4 \mathrm{~Hz}, 2 \mathrm{H}$ ), 1.66 $(\mathrm{tt}, J=7.7,7.4 \mathrm{~Hz}, 2 \mathrm{H}), 2.69(\mathrm{t}, J=7.7 \mathrm{~Hz}, 2 \mathrm{H}), 4.70(\mathrm{~d}, J$ $=5.7 \mathrm{~Hz}, 2 \mathrm{H}), 6.65(\mathrm{~s}, 1 \mathrm{H}), 7.29(\mathrm{t}, J=7.7 \mathrm{~Hz}, 1 \mathrm{H}), 7.38$ $(\mathrm{t}, J=7.7 \mathrm{~Hz}, 2 \mathrm{H}), 7.44(\mathrm{~d}, J=7.7 \mathrm{~Hz}, 2 \mathrm{H}), 7.67(\mathrm{~d}, J=7.5$ $\mathrm{Hz}, 2 \mathrm{H}), 7.70$ (d, $J=7.5 \mathrm{~Hz}, 2 \mathrm{H}) .{ }^{13} \mathrm{C} \mathrm{NMR}(125 \mathrm{MHz}$, $\left.\mathrm{CDCl}_{3}\right) \delta 14.0,22.6,25.7,32.1,65.2,109.3,123.8,124.1,125.5$, 126.8, 127.4, 128.6, 130.3, 131.7, 139.7, 148.0, 151.6. IR (KBr) $v 3327,3079,2949,2928,2849,1594,1500,1484,1464,1421$, 1282, 1186, 1044, 934, 809, 763, 694, 667, 508, $483 \mathrm{~cm}^{-1}$. HRFAB calcd for $\mathrm{C}_{21} \mathrm{H}_{22} \mathrm{O}_{2} 306.1620$, found 306.1615. Anal. Calcd for $\mathrm{C}_{21} \mathrm{H}_{22} \mathrm{O}_{2} \mathrm{C}, 82.32 ; \mathrm{H}, 7.24$. Found $\mathrm{C}, 81.79 ; \mathrm{H}$, 7.15.Teraryl-mono-bromide $(V c)$. Under argon atmosphere, a 
benzene solution $(10 \mathrm{~mL})$ of $\mathbf{V b}(0.61 \mathrm{~g}, 2.0 \mathrm{mmol})$ and $\mathrm{PBr}_{3}$ ( $d=2.88,0.2 \mathrm{~mL}, 2.1 \mathrm{mmol}$ ) was stirred for $12 \mathrm{~h}$ at room temperature. The mixture was treated with $10 \% \mathrm{NaHCO}_{3}(5$ $\mathrm{mL}$ ) and extracted with $\mathrm{CH}_{2} \mathrm{Cl}_{2}$. The organic layer was dried $\left(\mathrm{MgSO}_{4}\right)$, and then the solvent was removed in vacuo. The residue was recrystallized from hexane- $\mathrm{CH}_{2} \mathrm{Cl}_{2}$ to give the $\mathrm{Vc}$ (570 mg, 79\%) mp 79-80 ${ }^{\circ} \mathrm{C}:{ }^{1} \mathrm{H}$ NMR (400 MHz, $\mathrm{CDCl}_{3}$ ) $\delta 0.94(\mathrm{t}, J=7.4 \mathrm{~Hz}, 3 \mathrm{H}), 1.49$ (sextet, $J=7.4 \mathrm{~Hz}, 2 \mathrm{H}$ ), 1.72 (tt, $J=7.8,7.4 \mathrm{~Hz}, 2 \mathrm{H}), 2.75(\mathrm{t}, J=7.8 \mathrm{~Hz}, 2 \mathrm{H}), 4.59(\mathrm{~s}, 2$ $\mathrm{H}), 6.78(\mathrm{~s}, 1 \mathrm{H}), 7.34(\mathrm{tt}, J=7.4,1.4 \mathrm{~Hz}, 1 \mathrm{H}), 7.42-7.55$ (m, $4 \mathrm{H}), 7.70-7.80(\mathrm{~m}, 4 \mathrm{H}) .{ }^{13} \mathrm{C} \mathrm{NMR}\left(125 \mathrm{MHz}, \mathrm{CDCl}_{3}\right) \delta$ 14.0, 22.6, 25.7, 32.1, 33.6, 109.9, 123.9, 124.2, 125.6, 126.9, 128.6, 129.5, 130.9, 131.6, 136.4, 148.3, 151.3. IR (KBr) v 3055, 2951, 2927, 2858, 1611, 1499, 1484, 1464, 1443, 1420, 1224, 1197, 1091, 1057, 934, 838, 813, 761, 688, 667, $596 \mathrm{~cm}^{-1}$. HRFAB calcd for $\mathrm{C}_{21} \mathrm{H}_{21}{ }^{79} \mathrm{BrO} 368.0776$, found 368.0772. Anal. Calcd for $\mathrm{C}_{21} \mathrm{H}_{21} \mathrm{BrO} \mathrm{C}, 68.30 ; \mathrm{H}, 5.73$. Found $\mathrm{C}, 67.86 ; \mathrm{H}$, 6.01 .

Teraryl-mono-thiol (II). To a solution of $\mathrm{K}_{2} \mathrm{CO}_{3}(207 \mathrm{mg}$, $1.5 \mathrm{mmol}$ ) in DMF (4 mL) was slowly added a solution of freshly distilled thioacetic acid $(0.1 \mathrm{~mL}, 1.5 \mathrm{mmol})$ in DMF (2 $\mathrm{mL}$ ). After $10 \mathrm{~min}$, this solution was added to a solution of Vc (360 $\mathrm{mg}, 1.0 \mathrm{mmol}$ ) in DMF (4 mL), and then the mixture was stirred overnight under the exclusion of light. After removal of solvent, the residue was dissolved in $\mathrm{CH}_{2} \mathrm{Cl}_{2}(20 \mathrm{~mL})$ and washed with water and brine. The organic layer was dried $\left(\mathrm{MgSO}_{4}\right)$, and then the solvent was removed in vacuo. The residue $(232 \mathrm{mg}, 0.64 \mathrm{mmol})$ in $\mathrm{THF}(6 \mathrm{~mL})$ was allowed to react with $\mathrm{LAH}(38 \mathrm{mg}, 1.0 \mathrm{mmol})$ in THF $(6 \mathrm{~mL})$ solution at $0{ }^{\circ} \mathrm{C}$ for $10 \mathrm{~min}$, then warmed to room temperature and stirred for an additional $30 \mathrm{~min}$. The mixture was cooled to $0{ }^{\circ} \mathrm{C}$ and then treated with $3 \mathrm{~N}$ aqueous $\mathrm{HCl}$ under an argon atmosphere until all the solid had dissolved. The biphasic mixture was diluted with ether $(20 \mathrm{~mL})$ and water $(20 \mathrm{~mL})$. The organic layer was dried $\left(\mathrm{MgSO}_{4}\right)$, removed in vacuo, and the residue was chromatographed (silica gel, $\mathrm{CH}_{2} \mathrm{Cl}_{2}$ /hexane) to give II (267 $\mathrm{mg}, 83 \%$ for two steps): ${ }^{1} \mathrm{H} \mathrm{NMR}\left(300 \mathrm{MHz}, \mathrm{CDCl}_{3}\right) \delta 0.94$ (t, $J=7.4 \mathrm{~Hz}, 3 \mathrm{H}), 1.43$ (sextet, $J=7.4 \mathrm{~Hz}, 2 \mathrm{H}$ ), 1.66 (tt, $J$ $=7.7 \mathrm{~Hz}, 7.4 \mathrm{~Hz}, 2 \mathrm{H}), 1.76(\mathrm{t}, J=7.4 \mathrm{~Hz}, 1 \mathrm{H}), 2.68(\mathrm{t}, J=$ $7.7 \mathrm{~Hz}, 2 \mathrm{H}), 7.74(\mathrm{~d}, J=7.4 \mathrm{~Hz}, 2 \mathrm{H}), 6.63(\mathrm{~s}, 1 \mathrm{H}), 7.26(\mathrm{t}$, $J=7.8 \mathrm{~Hz}, 1 \mathrm{H}), 7.32(\mathrm{~d}, J=7.8 \mathrm{~Hz}, 2 \mathrm{H}), 7.42(\mathrm{t}, J=7.8$ $\mathrm{Hz}, 2 \mathrm{H}), 7.65(\mathrm{~d}, J=7.7 \mathrm{~Hz}, 2 \mathrm{H}), 7.67(\mathrm{~d}, J=7.7 \mathrm{~Hz}, 2 \mathrm{H})$. ${ }^{13} \mathrm{C}$ NMR $\left(75 \mathrm{MHz}, \mathrm{CDCl}_{3}\right) \delta 13.9,22.6,25.7,28.8,32.1,109.2$, 124.0, 124.1, 125.5, 126.8, 128.4, 128.5, 129.7, 131.8, 140.0, 148.0, 151.6. IR (KBr) v 3026, 2955, 2928, 2869, 2859, 2567, $1605,1597,1500,1486,1465,1251,1182,1109,1073,1051$, 933, 839, 811, $692 \mathrm{~cm}^{-1}$. HRFAB calcd for $\mathrm{C}_{21} \mathrm{H}_{22} \mathrm{OS} 322.1391$, found 322.1388. Anal. Calcd for $\mathrm{C}_{21} \mathrm{H}_{22} \mathrm{OS} \mathrm{C}$, 78.22; H, 6.88. Found C, 77.99; H, 7.10.

Synthesis of Ter- or Penta-aryl-bis-dithiol (III or IV). Teror Penta-aryl-bis-diol (VIb or VIIb). Under argon atmosphere, a THF solution $(60 \mathrm{~mL})$ of VIa or VIIa $(1.0 \mathrm{mmol})$ was treated with DIBALH $(8.0 \mathrm{~mL}$ of $1.0 \mathrm{M}$ solution, $8.0 \mathrm{mmol})$ at $0{ }^{\circ} \mathrm{C}$ and stirred for $30 \mathrm{~min}$. The mixture was stirred for $30 \mathrm{~min}$ at 0 ${ }^{\circ} \mathrm{C}$ and was gradually warmed to room temperature and then stirred for $5 \mathrm{~h}$. After quenching with $10 \% \mathrm{NH}_{4} \mathrm{Cl}(10 \mathrm{~mL})$ and extracted with ether, the organic layer was dried $\left(\mathrm{MgSO}_{4}\right)$, and the solvent was removed in vacuo. The residue material was recrystallized from $\mathrm{CH}_{2} \mathrm{Cl}_{2}$-hexane to give the alcohol VIb (312 $\mathrm{mg}, 93 \%)$ or VIIb $(486 \mathrm{mg}, 91 \%)$.VIb mp $113-114{ }^{\circ} \mathrm{C}:{ }^{1} \mathrm{H}$ NMR (400 MHz, $\left.\mathrm{CDCl}_{3}\right) \delta 0.94(\mathrm{t}, J=7.4 \mathrm{~Hz}, 3 \mathrm{H}), 1.42$ (sextet, $J=7.4 \mathrm{~Hz}, 2 \mathrm{H}), 1.65(\mathrm{tt}, J=7.4,7.8 \mathrm{~Hz}, 2 \mathrm{H}), 2.04$ (br, $2 \mathrm{H}), 2.66$ (t, $J=7.8 \mathrm{~Hz}, 2 \mathrm{H}), 4.65$ (s, $2 \mathrm{H}), 4.68$ (s, $2 \mathrm{H})$, $6.63(\mathrm{~s}, 1 \mathrm{H}), 7.34(\mathrm{~d}, J=8.2 \mathrm{~Hz}, 2 \mathrm{H}), 7.39(\mathrm{~d}, J=8.2 \mathrm{~Hz}$,

\section{CHART 3}

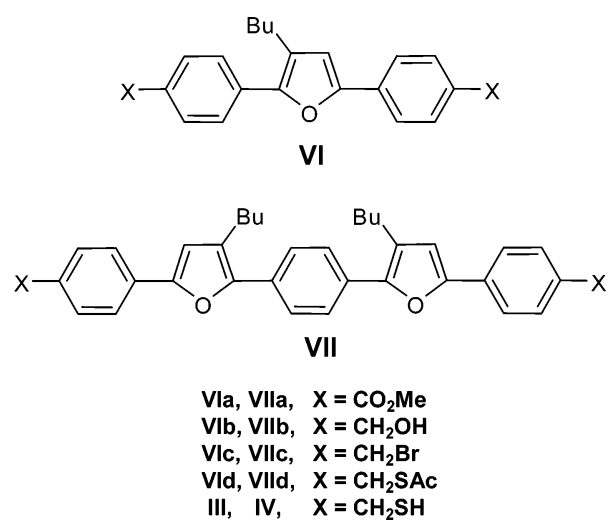

$2 \mathrm{H}), 7.65(\mathrm{~d}, J=8.2 \mathrm{~Hz}, 2 \mathrm{H}), 7.67(\mathrm{~d}, J=8.2 \mathrm{~Hz}, 2 \mathrm{H}) .{ }^{13} \mathrm{C}$ NMR $\left(100 \mathrm{MHz}, \mathrm{CDCl}_{3}\right) \delta 13.9,22.6,25.7,32.0,65.0,109.2$, $123.8,124.2$, 125.6, 127.2, 127.3, 130.1, 131.1, 139.3, 139.7, 147.7, 151.6.

VIIb mp 170-171 ${ }^{\circ} \mathrm{C}:{ }^{1} \mathrm{H}$ NMR $\left(300 \mathrm{MHz}, \mathrm{CDCl}_{3}\right) \delta 0.97$ (t, $J=7.3 \mathrm{~Hz}, 6 \mathrm{H}), 1.46$ (sextet, $J=7.3 \mathrm{~Hz}, 4 \mathrm{H}), 1.68(\mathrm{~s}, 2$ $\mathrm{H}$ ), 1.69 (quint, $J=7.6 \mathrm{~Hz}, 4 \mathrm{H}$ ), 2.73 (t, $J=7.6 \mathrm{~Hz}, 4 \mathrm{H}$ ), $4.70(\mathrm{~s}, 4 \mathrm{H}), 6.67(\mathrm{~s}, 2 \mathrm{H}), 7.38(\mathrm{~d}, J=8.2 \mathrm{~Hz}, 4 \mathrm{H}), 7.71$ (d, $J=8.2 \mathrm{~Hz}, 4 \mathrm{H}), 7.75(\mathrm{~s}, 4 \mathrm{H}) .{ }^{13} \mathrm{C} \mathrm{NMR}\left(100 \mathrm{MHz}, \mathrm{CDCl}_{3}\right)$ $\delta 14.0,22.7,25.9,32.1,65.2,109.5,123.9,124.5,125.5,127.4$, 130.0, 130.2, 139.8, 147.8, 151.7.

Ter- or Penta-aryl-bis-dibromide (VIc or VIIc). Under argon atmosphere, a benzene solution $(10 \mathrm{~mL})$ of VIb or VIIb $(1.0$ mmol) and $\operatorname{PBr}_{3}(d=2.88,0.2 \mathrm{~mL}, 2.1 \mathrm{mmol})$ was stirred for $12 \mathrm{~h}$. The mixture was treated with $10 \% \mathrm{NaHCO}_{3}(5 \mathrm{~mL})$ and extracted with $\mathrm{CH}_{2} \mathrm{Cl}_{2}$. The organic layer was dried $\left(\mathrm{MgSO}_{4}\right)$, and the solvent was removed in vacuo. The residue was recrystallized from hexane- $\mathrm{CH}_{2} \mathrm{Cl}_{2}$ to give VIc (432 $\mathrm{mg}, 94 \%$ ) or VIIc $(612 \mathrm{mg}, 93 \%)$.

VIc mp $116-117{ }^{\circ} \mathrm{C}:{ }^{1} \mathrm{H}$ NMR $\left(300 \mathrm{MHz}, \mathrm{CDCl}_{3}\right) \delta 0.97$ (t, $J=7.3 \mathrm{~Hz}, 3 \mathrm{H}$ ), 1.23 (sextet, $J=7.3 \mathrm{~Hz}, 2 \mathrm{H}$ ), 1.64 (tt, $J$ $=7.7,7.3 \mathrm{~Hz}, 2 \mathrm{H}), 2.70(\mathrm{t}, J=7.7 \mathrm{~Hz}, 2 \mathrm{H}), 4.52(\mathrm{~s}, 2 \mathrm{H})$, $4.54(\mathrm{~s}, 2 \mathrm{H}), 6.68(\mathrm{~s}, 1 \mathrm{H}), 7.42(\mathrm{~d}, J=8.3 \mathrm{~Hz}, 2 \mathrm{H}), 7.45(\mathrm{~d}$, $J=8.3 \mathrm{~Hz}, 2 \mathrm{H}), 7.66(\mathrm{~d}, J=8.2 \mathrm{~Hz}, 2 \mathrm{H}), 7.68(\mathrm{~d}, J=8.2$ $\mathrm{Hz}, 2 \mathrm{H}) .{ }^{13} \mathrm{C} \mathrm{NMR}\left(75 \mathrm{MHz}, \mathrm{CDCl}_{3}\right) \delta 14.0,22.6,25.8,32.0$, $33.5,70.8,110.0,124.0,125.0,125.7,129.4,129.5,130.7$, 131.7, 136.1, 136.6, 147.7, 151.6. IR (KBr) v 2959, 2932, 2862, 1614, 1511, 1228, 1203, 1096, 935, 841, 817, $601 \mathrm{~cm}^{-1}$. HRFAB calcd for $\mathrm{C}_{22} \mathrm{H}_{22} \mathrm{Br}_{2} \mathrm{O} 460.0037$, found 460.0044 .

VIIc mp $185-187{ }^{\circ} \mathrm{C}:{ }^{1} \mathrm{H}$ NMR $\left(300 \mathrm{MHz}, \mathrm{CDCl}_{3}\right) \delta 0.99$ (t, $J=7.2 \mathrm{~Hz}, 6 \mathrm{H}$ ), 1.47 (sextet, $J=7.2 \mathrm{~Hz}, 4 \mathrm{H}$ ), 1.70 (tt, $J$ $=7.6,7.2 \mathrm{~Hz}, 4 \mathrm{H}), 2.75(\mathrm{t}, J=7.6 \mathrm{~Hz}, 4 \mathrm{H}), 4.54(\mathrm{~s}, 4 \mathrm{H})$, $6.71(\mathrm{~s}, 2 \mathrm{H}), 7.42(\mathrm{~d}, J=8.1 \mathrm{~Hz}, 4 \mathrm{H}), 7.70(\mathrm{~d}, J=8.1 \mathrm{~Hz}, 4$ $\mathrm{H}), 7.77(\mathrm{~s}, 4 \mathrm{H}) .{ }^{13} \mathrm{C} \mathrm{NMR}\left(75 \mathrm{MHz}, \mathrm{CDCl}_{3}\right) \delta$ 14.0, 22.6, 25.9, 32.0, 33.6, 110.1, 123.9, 124.6, 125.5, 129.5, 129.9, 130.8, 136.5, 148.0, 151.3. IR (KBr) $v$ 2960, 2932, 2873, 1611, 1510, 1460, 1226, 1200, 1090, 934, 840, 814, 672, $596 \mathrm{~cm}^{-1}$. HRFAB calcd for $\mathrm{C}_{36} \mathrm{H}_{36} \mathrm{Br}_{2} \mathrm{O}_{2}$ 658.1082, found 658.1072.

Ter- or Penta-aryl-bis-dithioacetate (VId or VIId). To a solution of $\mathrm{K}_{2} \mathrm{CO}_{3}(3.0 \mathrm{mmol})$ in DMF $(10 \mathrm{~mL})$ was slowly added a solution of freshly distilled thioacetic acid $(0.2 \mathrm{~mL}$, $3.0 \mathrm{mmol})$ in DMF (5 mL). After $10 \mathrm{~min}$, this solution was added to a solution of VIc or VIIc $(1.0 \mathrm{mmol})$ in DMF (10 $\mathrm{mL}$ ), and the mixture was stirred overnight under the exclusion of light. After removal of solvent, the residue was dissolved in $\mathrm{CH}_{2} \mathrm{Cl}_{2}(40 \mathrm{~mL})$ and washed with water and brine. The organic layer was dried $\left(\mathrm{MgSO}_{4}\right)$, the solvent was removed in vacuo, and the residue was chromatographed (silica gel, EtOAc/hexane) to give VId (407 mg, 90\%) or VIId (598 mg, 92\%). 
VId: ${ }^{1} \mathrm{H} \mathrm{NMR}\left(300 \mathrm{MHz}, \mathrm{CDCl}_{3}\right) \delta 0.93(\mathrm{t}, J=7.2 \mathrm{~Hz}, 3$ H), 1.40 (sextet, $J=7.2 \mathrm{~Hz}, 2 \mathrm{H}$ ), 1.63 (tt, $J=7.7,7.2 \mathrm{~Hz}, 2$ H), 2.34 (s, $3 \mathrm{H}), 2.35$ (s, $3 \mathrm{H}), 2.64(\mathrm{t}, J=7.7 \mathrm{~Hz}, 2 \mathrm{H}), 4.11$ (s, $2 \mathrm{H}), 4.13$ (s, $2 \mathrm{H}), 6.60$ (s, $1 \mathrm{H}), 7.25$ (d, J=8.2 Hz, $2 \mathrm{H})$, $7.30(\mathrm{~d}, J=8.2 \mathrm{~Hz}, 2 \mathrm{H}), 7.58(\mathrm{~d}, J=8.0 \mathrm{~Hz}, 2 \mathrm{H}), 7.60(\mathrm{~d}$, $J=8.0 \mathrm{~Hz}, 2 \mathrm{H}) .{ }^{13} \mathrm{C}$ NMR $\left(75 \mathrm{MHz}, \mathrm{CDCl}_{3}\right) \delta 13.9,22.6$, 22.7, 25.7, 30.2, 30.3, 32.0, 33.2, 33.3, 41.2, 109.3, 123.8, 124.2, 125.6, 129.0, 129.8, 130.7, 136.0, 136.4, 147.6, 151.5, 195.0 . IR $(\mathrm{KBr}) v 2959,2931,2866,1692,1655,1509,1134,1104$, $958,626 \mathrm{~cm}^{-1}$; HRFAB calcd for $\mathrm{C}_{26} \mathrm{H}_{18} \mathrm{O}_{3} \mathrm{~S}_{2} 452.1480$, found 452.1483 .

VIId mp $142-143{ }^{\circ} \mathrm{C}:{ }^{1} \mathrm{H}$ NMR $\left(300 \mathrm{MHz}, \mathrm{CDCl}_{3}\right) \delta 0.98$ (t, $J=7.3 \mathrm{~Hz}, 6 \mathrm{H}$ ), 1.48 (sextet, $J=7.3 \mathrm{~Hz}, 4 \mathrm{H}$ ), 1.68 (tt, $J$ $=7.7,7.3 \mathrm{~Hz}, 4 \mathrm{H}), 2.37(\mathrm{~s}, 6 \mathrm{H}), 2.74(\mathrm{t}, J=7.7 \mathrm{~Hz}, 4 \mathrm{H})$, $4.14(\mathrm{~s}, 4 \mathrm{H}), 6.66(\mathrm{~s}, 2 \mathrm{H}), 7.31(\mathrm{~d}, J=8.2 \mathrm{~Hz}, 4 \mathrm{H}), 7.66(\mathrm{~d}$, $J=8.2 \mathrm{~Hz}, 4 \mathrm{H}), 7.75(\mathrm{~s}, 4 \mathrm{H}) .{ }^{13} \mathrm{C} \mathrm{NMR}\left(75 \mathrm{MHz}, \mathrm{CDCl}_{3}\right) \delta$ 14.0, 22.6, 25.9, 30.4, 32.1, 33.3, 109.5, 123.9, 124.5, 125.4, $129.2,129.8,129.9,136.5,147.7,151.6,195.1 . \mathrm{IR}(\mathrm{KBr}) v 2952$, 2924, 2860, 2568, 1685, 1510, 1488, 1137, 936, 834, 755, 670, $635 \mathrm{~cm}^{-1}$. HRFAB calcd for $\mathrm{C}_{40} \mathrm{H}_{42} \mathrm{O}_{4} \mathrm{~S}_{2}$ 650.2525, found 650.2520 .

Ter- or Penta-aryl-bis-dithiol (III or IV). Under argon atmosphere, a THF solution $(10 \mathrm{~mL})$ of LAH (3 equiv) was treated with THF solution $(10 \mathrm{~mL})$ of VId or VIId $(1.0 \mathrm{mmol})$ at $0{ }^{\circ} \mathrm{C}$, and stirred for $10 \mathrm{~min}$, then warmed to room temperature and stirred an additional $30 \mathrm{~min}$. The mixture was cooled to 0 ${ }^{\circ} \mathrm{C}$ and treated with $3 \mathrm{~N}$ aqueous $\mathrm{HCl}$ under an argon atmosphere until all the solid had dissolved. The biphasic mixture was diluted with ether $(20 \mathrm{~mL})$ and water $(20 \mathrm{~mL})$. The organic layer was dried $\left(\mathrm{MgSO}_{4}\right)$, removed in vacuo, and the residue was chromatographed (silica gel, $\mathrm{CH}_{2} \mathrm{Cl}_{2} /$ hexane) to give III (305 mg, 83\%) or IV (453 mg, 80\%).

III: ${ }^{1} \mathrm{H} \mathrm{NMR}\left(200 \mathrm{MHz}, \mathrm{CDCl}_{3}\right) \delta 0.96(\mathrm{t}, J=7.2 \mathrm{~Hz}, 3$ H), 1.45 (sextet, $J=7.2 \mathrm{~Hz}, 2 \mathrm{H}), 1.65(\mathrm{tt}, J=7.6,7.2 \mathrm{~Hz}, 2$ $\mathrm{H}), 1.78(\mathrm{t}, J=7.5 \mathrm{~Hz}, 1 \mathrm{H}), 1.80(\mathrm{t}, J=7.5 \mathrm{~Hz}, 1 \mathrm{H}), 2.69$ $(\mathrm{t}, J=7.6 \mathrm{~Hz}, 2 \mathrm{H}), 3.76(\mathrm{~d}, J=7.5 \mathrm{~Hz}, 2 \mathrm{H}), 3.78(\mathrm{~d}, J=7.5$ $\mathrm{Hz}, 2 \mathrm{H}), 6.65$ (s, $1 \mathrm{H}), 7.34$ (d, $J=8.2 \mathrm{~Hz}, 2 \mathrm{H}), 7.38$ (d, $J=$ $8.2 \mathrm{~Hz}, 2 \mathrm{H}), 7.65(\mathrm{~d}, J=8.1 \mathrm{~Hz}, 2 \mathrm{H}), 7.67(\mathrm{~d}, J=8.1 \mathrm{~Hz}$, $2 \mathrm{H}) .{ }^{13} \mathrm{C} \mathrm{NMR}\left(100 \mathrm{MHz}, \mathrm{CDCl}_{3}\right) \delta 14.0,22.6,25.8,28.80$, 28.82, 32.1, 109.2, 123.9, 124.2, 125.7, 128.3, 129.6, 130.6, 139.6, 140.0, 147.7, 151.6. IR (KBr) v 3030, 2959, 2931, 2872, 2862, 2568, 1607, 1510, 1494, 1252, 1104, 1052, 935, 841, 813 $\mathrm{cm}^{-1}$. HRFAB calcd for $\mathrm{C}_{22} \mathrm{H}_{24} \mathrm{OS}_{2} 368.1269$, found 368.1277 . Anal. Calcd for $\mathrm{C}_{22} \mathrm{H}_{24} \mathrm{OS}_{2} \mathrm{C}, 71.69 ; \mathrm{H}, 6.56$. Found C, 71.47; H, 6.22.

IV mp $125-129{ }^{\circ} \mathrm{C}:{ }^{1} \mathrm{H} \mathrm{NMR}\left(400 \mathrm{MHz}, \mathrm{CDCl}_{3}\right) \delta 0.96(\mathrm{t}$, $J=7.3 \mathrm{~Hz}, 6 \mathrm{H}), 1.45$ (sextet, $J=7.3 \mathrm{~Hz}, 4 \mathrm{H}), 1.68$ (tt, $J=$ 7.7, $7.3 \mathrm{~Hz}, 4 \mathrm{H}), 1.76(\mathrm{t}, J=7.5 \mathrm{~Hz}, 2 \mathrm{H}), 2.72(\mathrm{t}, J=7.7$ $\mathrm{Hz}, 4 \mathrm{H}), 3.75$ (d, $J=7.5 \mathrm{~Hz}, 4 \mathrm{H}), 6.65$ (s, $2 \mathrm{H}), 7.33$ (d, $J=$ $8.3 \mathrm{~Hz}, 4 \mathrm{H}), 7.66(\mathrm{~d}, J=8.3 \mathrm{~Hz}, 4 \mathrm{H}), 7.74(\mathrm{~s}, 4 \mathrm{H}) .{ }^{13} \mathrm{C}$ NMR $\left(75 \mathrm{MHz}, \mathrm{CDCl}_{3}\right) \delta 14.0,22.6,25.9,28.8,32.1,109.4$, $123.9,124.5,125.4,128.4,129.6,129.9,140.0,147.7,151.6$. IR (KBr) v 3023, 2956, 2927, 2868, 2857, 2562, 1607, 1598, 1509, 1486, 1250, 1190, 1104, 1060, 1019, 933, 833, 814, 794, $669 \mathrm{~cm}^{-1}$. HRFAB calcd for $\mathrm{C}_{40} \mathrm{H}_{42} \mathrm{O}_{4} \mathrm{~S}_{2}$ 566.2313, found 566.2311.

Preparation of Monolayers. The deposition solutions contained $0.24 \mathrm{mM}$ thiolated furan oligoaryls (II-IV) in THF. To prepare monolayers containing a single component, the soaking time of the gold substrate was ranging from $3 \mathrm{~h}$ to days. The sample was rinsed thoroughly in sequence with THF and ethanol. To remove trace amount of solvent, the sample was subjected to vacuum drying ( $\sim 30 \mathrm{~min}, 120 \mathrm{mTorr})$ prior to STM or IR measurements. To prepare mixed monolayers, the substrates were preassembled with $n$-dodecanethiol $(1 \mathrm{mM}$ in EtOH, $80 \mathrm{~min} \sim 12 \mathrm{~h})$. After rinsed thoroughly with ethanol, the substrates were treated with the same way as those for singlecomponent SAMs.

STM Measurements. The Au(111) substrates (Gold Arrandee, purchased from Metallhandel Schroer $\mathrm{GmbH}$, Germany) were $\sim 200-300 \mathrm{~nm}$ thick gold films with a $\sim 1-4 \mathrm{~nm}$ thick $\mathrm{Cr}$ adhesive layer and were flame annealed a few times before each experiment. STM measurements were carried out with a NanoScope IIIa (Veeco Metrology Group, Santa Barbara, CA) using a low-current modulus. Commercial Pt/Ir tips (Nanotips, Digital Instruments, Santa Barbara, CA) were employed. Typical imaging conditions of tunneling current and bias voltage were ranging from 10 to $15 \mathrm{pA}$ and from 1.2 to $2 \mathrm{~V}$, respectively. The microscope was housed in a chamber where dry $\mathrm{N}_{2}$ was purging throughout the experiments and the humidity was lower than $2 \%$.

IR Characterization. Transmission IR spectra of Compounds II-IV were obtained by $\mathrm{KBr}$-pelleted samples. For IRAS (infrared reflection-absorption spectroscopy) spectra of monolayer films, the substrates were 200-nm-thick gold films thermally evaporated onto glass slides precleaned with piranha solution, a 1:3 (v/v) mixture of $30 \% \mathrm{H}_{2} \mathrm{O}_{2}$ and concentrated $\mathrm{H}_{2} \mathrm{SO}_{4}$. This solution reacts violently with organic materials and should be handled with great care. The pressure in the belljar evaporator (Auto 306, Edwards High Vacuum International, West Sussex, UK) was nominally $2 \times 10^{-6}$ Torr. A 5-nm $\mathrm{Cr}$ underlayer was used to enhance the adhesion of the gold film. IRAS spectroscopy was carried out with a Perkin-Elmer System 2000 infrared spectrometer equipped with an MCT detector cooled with liquid nitrogen. The measurement scheme ${ }^{78}$ was a single reflection mode and the $p$-polarized light was incident at $85^{\circ}$ from the surface normal with a grazing angle accessory (FT-85, Spectra-Tech, Shelton, CT). The light path, detector, and sample chambers were purged with dry nitrogen. Both the sample and the reference (bare $\mathrm{Au}$ ) 1024 scans were collected at $4 \mathrm{~cm}^{-1}$ resolution for signal averaging.

Acknowledgment. We thank the National Science Council and the Ministry of Education (Taiwan, R.O.C.) for financial support. We also thank Professor M.-K. Leung for the fruitful discussion of the assembly mechanism of the mixed monolayers.

Supporting Information Available: Preliminary spectra of scanning tunneling spectroscopy for $n$-dodecanethiol SAMs and crystalline domains of III and IV (Figure S1). This material is available free of charge via the Internet at http://pubs.acs.org.

\section{References and Notes}

(1) Mullen, K., Wegner, G., Eds. Electronic Materials: The Oligomer Approach; Wiley-VCH: Weinheim, 1998.

(2) Tour, J. M. Acc. Chem. Res. 2000, 33, 791-804.

(3) Roncali, J. Chem. Rev. 1992, 92, 711-738. 1377.

(4) Martin, R. E.; Diederich, F. Angew. Chem., Int. Ed. 1999, 38, 1350-

(5) Tour, J. M. Chem. Rev. 1996, 96, 537-554.

(6) Roncali, J. Chem. Rev. 1997, 97, 173-206.

(7) Hucke, A.; Cava, M. P. J. Org. Chem. 1998, 63, 7413-7417.

(8) Dufresne, G.; Bouchard, J.; Belletete, M.; Durocher, G.; Leclerc, M. Macromolecules 2000, 33, 8252-8257.

(9) Roncali, J. J. Mater. Chem. 1997, 7, 2307-2321. 1409 .

(10) Segura, J. L.; Martin, N. Angew. Chem., Int. Ed. 2001, 40, 1372-

(11) Nielsen, M. B.; Utesch, N. F.; Moonen, N. N. P.; Boudon, C.; Gisselbrecht, J.-P.; Concilio, S.; Piotto, S. P.; Seiler, P.; Gunter, P.; Gross, M.; Diederich, F. Chem.-Eur. J. 2002, 8, 3601-3613.

(12) Otsubo, T.; Takimiya, K. Bull. Chem. Soc. Jpn. 2004, 77, 43-58. 551 .
(13) Niziurski-Mann, R. E.; Cava, M. P. Adv. Mater. 1993, 5, 547- 
(14) Niziurski-Mann, R. E.; Scordilis-Kelley, C.; Liu, T.-L.; Cava, M. P.; Carlin, R. T. J. Am. Chem. Soc. 1993, 115, 887-891. 379.

(15) Gandini, A.; Belgacem, M. N. Prog. Polym. Sci. 1997, 22, 1203-

(16) Saadeh, H.; Goodson, T., III.; Yu, L. Macromolecules 1997, 30, $4608-4612$

(17) Politis, J. K.; Nemes, J. C.; Curtis, M. D. J. Am. Chem. Soc. 2001, $123,2537-2547$

(18) Pyo, S. M.; Kim, S. I.; Shim, T. J.; Park, H. K.; Ree, M.; Park, K. H.; Kang, J. S. Macromolecules 1998, 31, 4777-4781.

(19) Lee, C.-F.; Yang, L.-M.; Hwu, T.-Y.; Feng, A.-S.; Tseng, J.-C.; Luh, T.-Y. J. Am. Chem. Soc. 2000, 122, 4992-4993.

(20) Liu, C.-Y.; Luh, T.-Y. Org. Lett. 2002, 4, 4305-4307.

(21) Lee, C.-F.; Liu, C.-Y.; Song, H.-C.; Luo, S.-J.; Tseng, J.-C.; Tso, H.-H.; Luh, T.-Y. Chem. Commun. 2002, 2824-2825.

(22) Tseng, J.-C.; Huang, S.-L.; Tin, C.-L.; Lin, H.-C.; Jin, B.-Y.; Chen, C.-Y.; Yu, J.-K.; Chou, P.-T.; Luh, T.-Y. Org. Lett. 2003, 5, 4381-4384. (23) Zhang, L.-Z.; Chen, C.-W.; Lee, C.-F.; Wu, C.-C.; Luh, T.-Y. Chem. Commun. 2002, 2336-2337.

(24) Wu, C.-C.; Hung, W.-Y.; Liu, T.-L.; Zhang, L.-Z.; Luh, T.-Y. J. Appl. Phys. 2003, 93, 5465-5471.

(25) Schonherr, G.; Bassler, H.; Silver, M. Philos. Mag. B 1981, 44 $47-61$.

(26) Borsenberger, P. M.; Pautmeier, L.; Bassler, H. J. Chem. Phys. 1991, 94, 5447-5454.

(27) Arkhipov, V. I.; Bassler, H.; Rudenko, A. I. Philos. Mag. B 1992, 65, 615-619.

(28) Bassler, H. Phys. Status Solidi B 1993, 175, 15-56.

(29) Borsenberger, P. M.; Weiss, D. S. Organic Photoreceptors for Imaging Systems; Marcel Dekker: New York, 1993.

(30) Bassler, H. Int. J. Mod. Phys. B 1994, 8, 847-854.

(31) de Boer, B.; Meng, H.; Perepichka, D. F.; Zheng, J.; Frank, M.

M.; Chabal, Y. J.; Bao, Z. Langmuir 2003, 19, 4272-4284.

(32) de Boer, B.; Frank, M. M.; Chabal, Y. J.; Jiang, W.; Garfunkel,

E.; Bao, Z. Langmuir 2004, 20, 1539-1542.

(33) Ulman, A. Chem. Rev. 1996, 96, 1533-1554.

(34) Sabatani, E.; Cohen-Boulakia, J.; Bruening, M.; Rubinstein, I. Langmuir 1993, 9, 2974-2981.

(35) Tao, Y.-T.; Wu, C.-C.; Eu, J.-Y.; Lin, W.-L.; Wu, K.-C.; Chen, C.-h. Langmuir 1997, 13, 4018-4023.

(36) Zharnikov, M.; Grunze, M. J. Phy.: Condens. Matter 2001, 13, $11333-11365$

(37) Yang, G.; Liu, G.-Y. J. Phys. Chem. B 2003, 107, 8746-8759.

(38) Kang, J. F.; Ulman, A.; Liao, S.; Jordan, R.; Yang, G.; Liu, G.-Y. Langmuir 2001, 17, 95-106.

(39) Yang, G.; Qian, Y.; Engtrakul, C.; Sita, L. R.; Liu, G.-Y. J. Phys. Chem. B 2000, 104, 9059-9062.

(40) Xia, Y.; Rogers, J. A.; Paul, K. E.; Whitesides, G. M. Chem. Rev. 1999, 99, 1823-1848.

(41) Schreiber, F. Prog. Surf. Sci. 2000, 65, 151-256.

(42) Azzam, W.; Cyganik, P.; Witte, G.; Buck, M.; Woll, Ch. Langmuir 2003, 19, 8262-8270.

(43) Lin, S.-Y.; Chen, I-W. P.; Chen, C.-h.; Hsieh, M.-H.; Yeh, C.-Y.; Lin, T.-W.; Chen, Y.-H.; Peng, S.-M. J. Phys. Chem. B 2004, 108, 959964.

(44) Cyganik, P.; Buck, M.; Azzam, W.; Woll, Ch. J. Phys. Chem. B 2004, 108, 4989-4996.

(45) Ishida, T.; Mizutani, W.; Aya, Y.; Ogiso, H.; Sasaki, S.; Tokumoto, H. J. Phys. Chem. B 2002, 106, 5886-5892.

(46) Yang, Y.-C.; Yen, Y.-P.; Ou Yang, L.-Y.; Yau, S.-L.; Itaya, K. Langmuir 2004, 20, 10030-10037.

(47) Reed, M. A.; Zhou, C.; Muller, C. J.; Burgin, T. P.; Tour, J. M. Science 1997, 278, 252-254.

(48) Cygan, M. T.; Dunbar, T. D.; Arnold, J. J.; Bumm, L. A.; Shedlock, N. F.; Burgin, T. P.; Jones, L., II; Allara, D. L.; Tour, J. M.; Weiss, P. S. J. Am. Chem. Soc. 1998, 120, 2721-2732.

(49) Chen, J.; Reed, M. A.; Rawlett, A. M.; Tour, J. M. Science 1999 $286,1550-1552$.

(50) Chen, J.; Wang, W.; Reed, M. A.; Rawlett, A. M.; Price, D. W., Jr.; Tour, J. M. Appl. Phys. Lett. 2000, 77, 1224-1226.

(51) Donhauser, Z. J.; Mantooth, B. A.; Kelly, K. F.; Bumm, L. A.; Monnell, J. D.; Stapleton, J. J.; Price, D. W., Jr.; Rawlett, A. M.; Allara, D. L.; Tour, J. M.; Weiss, P. S. Science 2001, 292, 2303-2307.
(52) Fan, F.-R. F.; Yang, J.; Dirk, S. M.; Price, D. W.; Kosynkin, D.; Tour, J. M.; Bard, A. J. J. Am. Chem. Soc. 2001, 123, 2454-2455.

(53) Rawlett, A. M.; Hopson, T. J.; Nagahara, L. A.; Tsui, R. K.; Ramachandran, G. K.; Lindsay, S. M. Appl. Phys. Lett. 2002, 81, 30433045 .

(54) Fan, F.-R. F.; Yang, J.; Cai, L.; Price, D. W., Jr.; Dirk, S. M.; Kosynkin, D. V.; Yao, Y.; Rawlett, A. M.; Tour, J. M.; Bard, A. J. J. Am. Chem. Soc. 2002, 124, 5550-5560.

(55) Zhitenev, N. B.; Erbe, A.; Bao, Z. Phys. Rev. Lett. 2004, 92, 186805/ $1-186805 / 4$.

(56) Sellers, H.; Ulman, A.; Shnidman, Y.; Eilers, J. E. J. Am. Chem. Soc. 1993, 115, 9389-9401.

(57) Jung, H. H.; Won, Y. D.; Shin, S.; Kim, K. Langmuir 1999, 15 , $1147-1154$

(58) Szafranski, C. A.; Tanner, W.; Laibinis, P. E.; Garrell, R. L. Langmuir 1998, 14, 3570-3579.

(59) Carron, K. T.; Hurley, L. G. J. Phys. Chem. 1991, 95, 9979-9984

(60) Dhirani, A.-A.; Zehner, R. W.; Hsung, R. P.; Guyot-Sionnest, P ;

Sita, L. R. J. Am. Chem. Soc. 1996, 118, 3319-3320.

(61) Zhong, C.-J.; Brush, R. C.; Anderegg, J.; Porter, M. D. Langmuir $1999,15,518-525$

(62) Frey, S.; Stadler, V.; Heister, K.; Eck, W.; Zharnikov, M.; Grunze, M.; Zeysing, B.; Terfort, A. Langmuir 2001, 17, 2408-2415.

(63) Nielsen, J. U.; Esplandiu, M. J.; Kolb, D. M. Langmuir 2001, 17, $3454-3459$

(64) Whelan, C. M.; Barnes, C. J.; Walker, C. G. H.; Brown, N. M. D. Surf. Sci. 1999, 425, 195-211.

(65) Sturrock, E. J.; Chen, Q.; Borchardt, P. H.; Richardson, N. V. J. Electron Spectrosc. Relat. Phenom. 2004, 135, 127-134.

(66) Duan, L.; Garrett, S. J. J. Phys. Chem. B 2001, 105, 9812-9816.

(67) Rico, M.; Barrachina, M.; Orza, J. M. J. Mol. Spectrosc. 1967, 24, $133-148$

(68) Yan, F. Q.; Qiao, M. H.; Wei, X. M.; Liu, Q. P.; Deng, J. F.; Xu, G. Q. J. Chem. Phys. 1999, 111, 8068-8076.

(69) Varsanyi, G. Assignments for Vibrational Spectra of Seven Hundred Benzene Derivatives; Wiley: New York, 1974.

(70) Joo, S. W.; Chung, T. D.; Jang, W.; Gong, M.-s.; Geum, N.; Kim, K. Langmuir 2002, 18, 8813-8816.

(71) Joo, S. W.; Han, S. W.; Kim, K. J. Phys. Chem. B 1999, 103, 10831-10837.

(72) Snyder, R. G. J. Mol. Spectrosc. 1961, 7, 116-144.

(73) Porter, M. D.; Bright, T. B.; Allara, D. L.; Chidsey, C. E. D. J. Am. Chem. Soc. 1987, 109, 3559-3568.

(74) Nuzzo, R. G.; Dubois, L. H.; Allara, D. L. J. Am. Chem. Soc. 1990, $112,558-569$.

(75) Walczak, M. M.; Chung, C.; Stole, S. M.; Widrig, C. A.; Porter, M. D. J. Am. Chem. Soc 1991, 113, 2370-2378.

(76) Laibinis, P. E.; Whitesides, G. M.; Allara, D. L.; Tao, Y.-T.; Parikh, A. N.; Nuzzo, R. G. J. Am. Chem. Soc. 1991, 113, 7152-7167.

(77) Armstrong, D. R.; Clarkson, J.; Smith, W. E. J. Phys. Chem. 1995 99, 17825-17831.

(78) Pemble, M. In Surface Analysis: The Principal Techniques Vickerman, J. C., Ed.; John Wiley \& Sons: New York, 1997; pp 278282

(79) Greenler, R. G. J. Chem. Phys. 1966, 44, 310-315.

(80) Benitez, G.; Vericat, C.; Tanco, S.; Lenicov, F. R.; Castez, M. F.; Vela, M. E.; Salvarezza, R. C. Langmuir 2004, 20, 5030-5037.

(81) Darling, S. B.; Rosenbaum, A. W.; Wang, Y.; Sibener, S. J. Langmuir 2002, 18, 7462-7468.

(82) Noh, J.; Hara, M. Langmuir 2001, 17, 7280-7285.

(83) Poirier, G. E.; Fitts, W. P.; White, J. M. Langmuir 2001, 17, 11761183

(84) Poirier, G. E. Langmuir 1999, 15, 1167-1175.

(85) Godin, M.; Williams, P. J.; Tabard-Cossa, V.; Laroche, O.; Beaulieu,

L. Y.; Lennox, R. B.; Grutter, P. Langmuir 2004, 20, 7090-7096.

(86) Poirier, G. E. Chem. Rev. 1997, 97, 1117-1128.

(87) Poirier, G. E.; Pylant, E. D. Science 1996, 272, 1145-1148.

(88) Kakiuchi, T.; Sato, K.; Iida, M.; Hobara, D.; Imabayashi, S.-i.; Niki, K. Langmuir 2000, 16, 7238-7244.

(89) Collard, D. M.; Fox, M. A. Langmuir 1991, 7, 1192-1197.

(90) Chidsey, C. E. D.; Bertozzi, C. R.; Putvinski, T. M.; Mujsce, A. M. J. Am. Chem. Soc. 1990, 112, 4301-4306. 